\title{
Urothelial Bladder Carcinoma in a 17-Year Old Male: A Case Report and Review of the Literature
}

\section{On Yedi Yașında Erkek Hastada Ürotelyal Mesane Karsinomu: Olgu Sunumu ve Literatürün Gözden Geçirilmesi}

\author{
Yasin Ceylan MD1, Bülent Günlüsoy MD1, Tansu Değirmenci MD1, Hakan Postacı MD2, Zafer Kozacıoğlu MD1 \\ ${ }^{1}$ Bozyaka Education and Research Hospital, Clinic of Urology, Izmir, Turkey \\ 2Bozyaka Education and Research Hospital, Clinic of Patology, Izmir, Turkey
}

\begin{abstract}
Summary
A rare case of urothelial bladder carcinoma in a 17-year old male was presented. The main finding was painless and intermittent hematuria for 2 days. In ultrasonography, there was a bulging mass into the bladder cavity on the right side of bladder base that mesaured $2.5 \times 3$ $\mathrm{cm}$. Transurethral resection was performed and pathologic report confirmed urothelial carcinoma. The histopathology demonstrated low grade papillary urothelial carcinoma, WHO I, and ISUP: low grade. P53 staining was positive. The tumor was limited in the bladder. Hematuria in a young patient should be investigated in detail and urothelial bladder cancer shoud be kept in mind for differential diagnosis.

Key Words: Urinary bladder neoplasm, adolescent, prognosis
\end{abstract}

\section{Özet}

On yedi yaşında ürotelyal mesane kanseri olan nadir bir olgu sunuldu. Ana bulgu 2 gündür süren ağrısız aralıkıı kanama idi. Ultrasonografide mesane sağ yan duvardan lümene doğru uzanan $2,5 \times 3 \mathrm{~cm}$ kitle saptandı. Transüretral rezeksiyon yapıldı ve patolojik olarak ürotelyal kasinom olduğu doğrulandı. Histopatolojik sonucu düşük gradeli ve p53 boyaması pozitif idi. Tümör mesaneye sınırlı idi. Ürotelyal mesane karsinomu, genç hastalarda ortaya çıkan hematüri olgularında akılda tutulmalıdır.

Anahtar Kelimeler: Mesane kanseri, adölesan, prognoz

\section{Introduction}

Bladder cancer is a disease that afflicts mostly the middle-aged or the elderly people, as the majority of any cancer type. More than $90 \%$ of bladder cancers are transitional cell carcinoma (TCC) with a male to female ratio of 7:1 (1). In a great majority of patients, it affects patients in their sixth or seventh decade of life (2). Urothelial neoplasms in patients younger than 30 years are rare. The impact of the age at onset on tumor biology and prognosis of patients remains controversial (2). There is still conflicting evidence regarding clinical behavior, disease recurrence, and progression in young patients who have been diagnosed with urothelial bladder carcinoma.

We present a rare case of a 17-year-old boy with urothelial cell carcinoma of the bladder and discuss the clinical behavior and prognosis of this type of carcinoma in young adults.

\section{Case Report}

A 17-year-old healthy boy presented with painless and intermittent hematuria for 2 days. There was no history of stone disease or urological malignancies in patient's family. Results of his laboratory tests were normal, and red blood cells were seen on urinalysis. Further investigation with ultrasound revealed a bulging mass into the bladder cavity on the right side of bladder base that mesaured $2.5 \times 3 \mathrm{~cm}$ (Figure 1). The kidneys were normal on ultrasonography. Transurethral resection was performed and pathologic report confirmed urothelial carcinoma (Figure 1). The histopathology demonstrated low grade papillary urothelial carcinoma, WHO grade I, and ISUP: low grade (Figure 2). Low grade papillary urothelial carcinoma is classified between bladder papilloms and malignancies. Cells are relatively uniform in size without significant nuclear pleomorphism or nucleomegaly. There is no evidence of cohesion between cells. Nucleoli may not be present. Numerous mitotic figures are rare and only on basement membrane. P53 staining was positive. The tumor was limited in the bladder. The patient controlled at 9. month after the operation by using ultrasonography, cystoscopy and cytology. There was no recurrence.

\section{Discussion}

Among various tumors in the urinary system, bladder tumors develop with a comparatively high frequency and are considered to be one of the most significant tumors in clinical practice. On the other hand, urothelial carcinoma of the urinary bladder is rare in young adults, as less than $1 \%$ of such tumors present in 


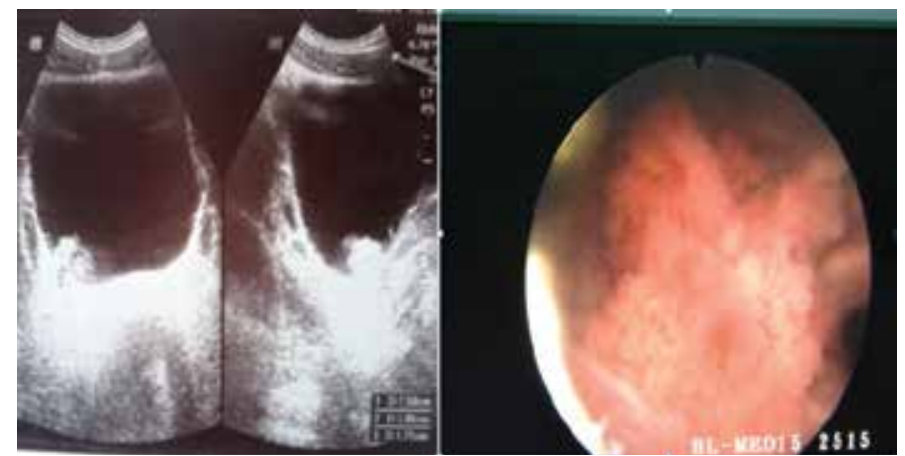

Figure 1. Ultrasonography and intraoperative appearance of the bladder tumor in a 17 years old young man

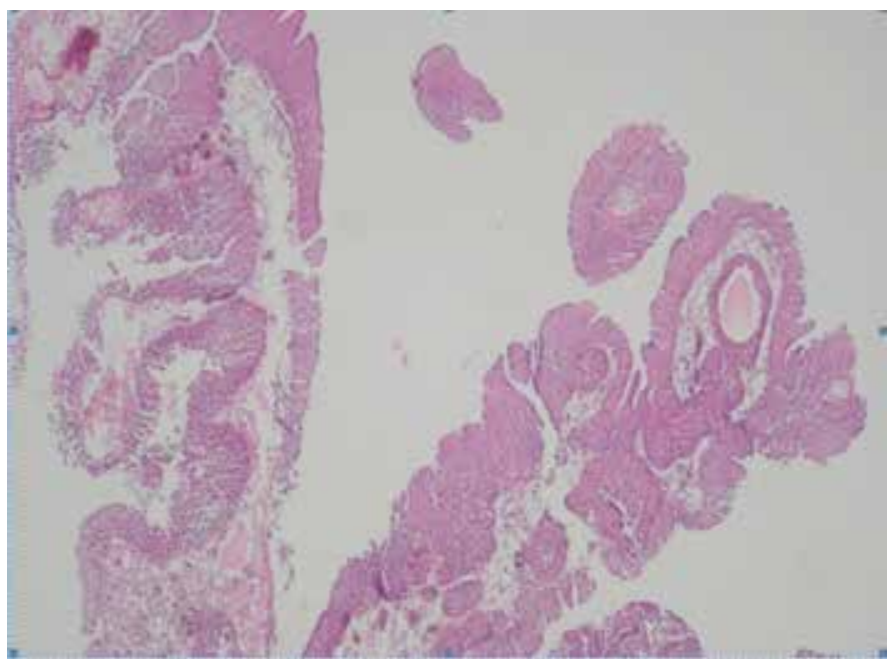

Figure 2. Histopathological examination reveal low grade papillary urothelial carcinoma

the first 4 decades of life (3). There is a male predominence of urothelial bladder carcinoma in young adults (3).

The clinical symptoms of gross hematuria which is the most common presenting symptom in young adults and irritative bladder symptoms should alert physicans to manifest the underlying etiology. Ultrasonography is a good choice as the beginning radiologic examination. Computarized tomography can be done in suspected cases for differential diagnosis. The duration from the initial symptom to the definitive diagnosis can be longer in younger patients as compared with older patients due to the fact that younger patients tend to be reluctant to undergo cystoscopy. These tumors in younger patients are often diagnosed as nephritis without sufficient examination. And also this delay seems to be common in younger patients because of low incidence of bladder cancer in this age group and the predominence of benign causes of hematuria in this age group causing hesitancy for an aggressive work-up.

Patients under 40 years old usually present with low-stage and low-grade bladder cancer. After analyzing the tumor grade in different age groups, Poletajew et al. (2) concluded that age correlates with risk of presence of poorly differentiated tumors. Lerana et al. (4) reported a 100\% incidence of low grade carcinomas in an analysis of urothelial bladder carcinoma in six children. The predominance of low grade tumors in urothelial bladder cancer patients aged $<40$ years were shown in many studies (5). It was suggested that the more favorable prognosis reported in some cases simply reflected the lower grade and stage of tumors at diagnosis in the young than in the old patients $(1,6,7)$. The results of a majority of previously studies exhibited a significantly higher rate of muscle-invasive bladder cancer among patients aged $>50$ years compared to younger patients (2). Among this age group, the survival rate in patients with invasive bladder cancer appears to be no worse than that in patients with superficial bladder cancer (3).

Although many reports exist regarding clinical characteristics and treatment for such tumors, there is still much debate regarding clinical progression and prognosis. p53 expression was found to be high in a immunohistochemical study examing bladder tumors in young adults (8). Ozbey et al. reported that the natural history of urothelial carcinoma in chidren is the same as adults (9). They showed a $36 \%$ incidence of muscleinvasive urothelial bladder cancer in 25 patients aged $<40$ years. In a recent meta-analysis, Paner et al. concluded that tumor recurrence and progression were infrequent in the first 2 decades and incresaed gradually in each successive decade, likely influenced by the increased proportion of higher-grade and higher-stage tumors (10).

In conclusion, hematuria in a young patient should be investigated in detail and urothelial bladder cancer shoud be kept in mind for differential diagnosis. Urothelial bladder cancer in young patients has a more favorable prognosis due to low stage and low grade. But there is a risk of recurrence and progression in patients with high grade tumors.

\section{Conflict of interest: The authors reported no conflict of interest related to this article.}

\section{References}

1. Landis SH, Murray T, Bolden S, Wingo PA. Cancer statistics, 1999. CA Cancer J Clin 1999;49:8-31, 1.

2. Poletajew $S$, Waledziak $M$, Fus $L$, et al. Urothelial bladder carcinoma in young patients is characterized by a relatively good prognosis. Ups J Med Sci 2012; 117:47-51.

3. Wen YC, Kuo JY, Chen KK, et al. Urothelial carcinoma of the urinary bladder in young adults--Clinical experience at Taipei Veterans General Hospital. J Chin Med Assoc 2005;68:272-275.

4. Lerana J, Krauel L, García-Aparicio L, et al. Transitional cell carcinoma of the bladder in children and adolescents: six-case series and review of the literature. J Pediatr Urol 2010;6:481-485.

5. Madrid García FJ, Parra Muntaner L, Rivas Escudero JA, et al. Transitional cell bladder carcinoma in patients younger than 40 years of age. Arch Esp Urol 1998;51:991-994.

6. Migaldi M, Rossi G, Maiorana A, et al. Superficial papillary urothelial carcinomas in young and elderly patients: a comparitive study. BJU Int 2004;94:311-316.

7. Cho KS, Hwang TK, Kim BW, et al. Differences in tumor characteristics and prognosis in newly diagnosed $\mathrm{Ta}, \mathrm{T} 1$ urothelial carcinoma of bladder according to patient age. Urology 2009;73:828-832.

8. Linn JF, Sesterhenn I, Mostofi FK, Schoenberg M. The molecular characteristics of bladder cancer in young patients. J Urol 1998; 159:1493-1496.

9. Ozbey I, Aksoy $\mathrm{Y}$, Bicgi O, et al. Transitional cell carcinoma of the bladder in patients under 40 years of age. Int Urol Nephrol 1999;31:655-659.

10. Paner GP, Zehnder P, Amin M, et al. Urothelial neoplasms of the urinary bladder occuring in young adult and pediatric patients: a comphrensive review of literature with implications for patient management. Adv Anatomic Path 2011;18:79-89. 